\title{
GM AND KM ALLOTYPES IN EIGHT TRIBAL POPULATIONS OF MADYHA PRADESH AND ORISSA, INDIA
}

\author{
Hubert WAlter, ${ }^{1, *}$ Hideo MATSUmoto, ${ }^{2}$ Heidi Danker-Hopfe, ${ }^{1}$ \\ Kailash C. MAlhotra, ${ }^{3}$ and Biswa N. MUKherJeE ${ }^{3}$ \\ ${ }^{1}$ Department of Human Biology, University of Bremen, D-28334 Bremen, Germany \\ ${ }^{2}$ Department of Legal Medicine, Osaka Medical School, 2-7 Daigaku-cho, \\ Takatsuki, Osaka 569, Japan \\ ${ }^{3}$ Anthropometry and Human Genetics Unit, Indian Statistical \\ Institute, Calcutta-700035, India
}

\begin{abstract}
Summary Serum samples from eight endogamous Indian tribal populations of Madhya Pradesh (Dhurwa, Halba, Bhatra, Muria, Maria) and Orissa (Deshia Khond, Binjhal, Kisan) with a total of $\mathrm{n}=731$ unrelated individuals were typed for GIM $(1,2,3,17)$, G3M $(5,10,11,13,14,15,16,21$, 26), and $K M$ (1). In seven of these populations five different GM haplotypes were found: $G M^{*} 1,17 ; 21,26 ; G M^{*} 1,17 ; 10,11,13,15,16 ; G M^{*} 1,2$, $17 ; 21,26 ; G M^{*} 1,3 ; 5,10,11,13,14,26$; and $G M^{*} 3 ; 5,10,11,13,14,26$. In the Kisan sample the haplotype $G M^{*} 1,2,17 ; 21,26$ is absent. The intergroup variability in the distribution of these haplotypes is considerable and statistically highly significant. The reasons for that can be attributed to the ethnohistory and to the genetic isolation of these eight endogamous tribal populations. The GM haplotype distribution pattern of all these groups is quite different from that of the non-tribal populations of India, whereas it is in good agreement with that of the so far tested other tribal populations from India. This can be explained by different origin and history of the Indian tribal and non-tribal populations. In the KM system, too, remarkable variability is seen in the distribution of phenotype and allele frequencies among the eight tribal populations under study.
\end{abstract}

Key Words GM and KM allotypes, Indian tribal populations, Central India, genetic differentiation

\section{INTRODUCTION}

Since the first study on the distribution of GM allotypes in India by Vos et

Received September 30, 1996; Revised version accepted November 28, 1996.

* To whom correspondence should be addressed. 
al. (1963) many investigations have been conducted on a large number of Indian populations for GM and KM markers, which showed the considerable value of these two polymorphic serum protein systems for the evaluation of genetic differentiation processes among the populations of the Indian subcontinent. The results of these studies have been summarized critically by Steinberg (1973), Steinberg and Cook (1981), and more recently by Walter et al. (1991) and Bhasin et al. (1992). Unfortunately, however, most of the hitherto published GM studies on Indian populations have considered only a few of the numerous GM markers. Therefore, in view of the complexity of the GM polymorphism, our knowledge concerning the distribution of GM allotypes among Indian populations is still limited. Larger sets of GM allotypes have been examined so far only by Daveau et al. (1980), Ray and Field (1981), Schanfield and Kirk (1981), Field et al. (1988) and Walter et al. (1987).

This study of eight endogamous tribal populations of Madhya Pradesh and Orissa shall contribute to our knowledge of the distribution of GM and KM allotypes among Indian populations. It is part of an extensive population genetic survey in these hitherto scarcely investigated regions of India. The distribution patterns of the allele frequencies of six polymorphic blood group systems (AlA2B0, MNSs, Rhesus, Kell, Duffy, Diego), three polymorphic serum protein systems (HP, GC, PI), five polymorphic red cell enzyme systems (ACP1, ESD, PGD, GLO1, LDH) and haemoglobin variants have been analyzed already and were reported elsewhere (Walter et al., 1992, 1993; Das et al., 1993).

\section{MATERIALS AND METHODS}

Serum samples from a total of $n=721$ unrelated male and female individuals belonging to eight different tribal populations from Madhya Pradesh and Orissa were collected in early 1989. These samples were air-mailed to the Department of Legal Medicine, Osaka Medical School, Osaka, Japan, where GM and KM typings were done. All the samples were tested for GM1M $(1,2,3,17)$, GM3M $(5,10,11,13$, $14,15,16,21,26)$, and $\mathrm{KM}(1)$. The reagents used for that are presented in Table 1 . Haplotype frequencies and degree of fit with the Hardy-Weinberg equilibrium were estimated in Bremen, using the computer program MAXIM (Kurczynski and Steinberg, 1967).

\section{THE POPULATIONS}

Our project in Madhya Pradesh, Orissa (and the eastern regions of Maharashtra) actually included 16 different tribal populations from various regions of these three federal states of India. However, due to lack of sufficient serum only eight of these tribal populations could be tested for GM and KM allotypes. The geographic location of these populations is shown in Fig. 1. Some brief ethnographic charac- 
Table 1. Reagents used for GM and KM allotype determinations.

\begin{tabular}{cccc}
\hline Alphabetic & Numerical & Antiallotype & Anti-Rho \\
\hline GIM & 1 & & \\
a & 2 & 3552 & 2880 \\
X & 3 & 2894 & 2880 \\
$f$ & 17 & 2871 & Ko-Ro \\
Z & & 3272 & 2880 \\
G3M & 5 & & \\
b1 & 11 & 7514 & 3656 \\
b0 & 13 & 0058 & 3656 \\
b3 & 14 & 4721 & 3656 \\
b4 & 10 & 0663 & 3656 \\
b5 & 21 & 1340 & 3656 \\
g & 15 & 1642 & 3359 \\
S & 16 & 2624 & 3068 \\
t & 26 & J198 & 3068 \\
u & & 1369 & Eggen \\
KM & 1 & & 2447 \\
\hline
\end{tabular}

teristics of them are given in the following, for more details see Fuchs (1973) and Walter et al. (1992).

Deshia Khond. This group is part of the Khond group of tribes and is concentrated in the Kalahandi District of Orissa, where the samples tested came from. The Deshia Khond speak a Dravidian language, and are separated into a number of subgroups, which are more or less genetically isolated from each other by social endogamy. They practise a traditional type of agriculture. According to the anthropological classification of the Indian populations proposed by Guha (1935) the Deshia Khond are of the Proto-Australoid racial type, and following Risley (1915) one cannot exclude some Mongoloid influence in their physical appearance.

Binjhal. The Binjhal are a little known tribal population living in Orissa and Madhya Pradesh. They are mainly concentrated in the Sambalpur District of Orissa, where our tested samples came from. The Binjhal are mainly settled agriculturists and speak a language, which belongs to the Indo-European language family. It is not unlikely that the Binjhal--like many other Indian tribal groups - have lost their own language and adopted an Indo-European one. Anthropologically they belong also to the Proto-Australoids (Guha, 1935).

Kisan. The Kisan are now mainly settled agriculturists and are living in the Chota Nagpur District of Madhya Pradesh and Bihar as well as in the Sambalpur District of Orissa. The tested samples originated in the latter area. Their language belongs to the Austro-Asiatic language family. Anthropologically they belong to the Proto-Australoids (Guha, 1935).

Dhurwa. The Dhurwa, also known as Parja, are a Dravidian speaking tribal population, living in the Bastar District of Madhya Pradesh. They are settled 


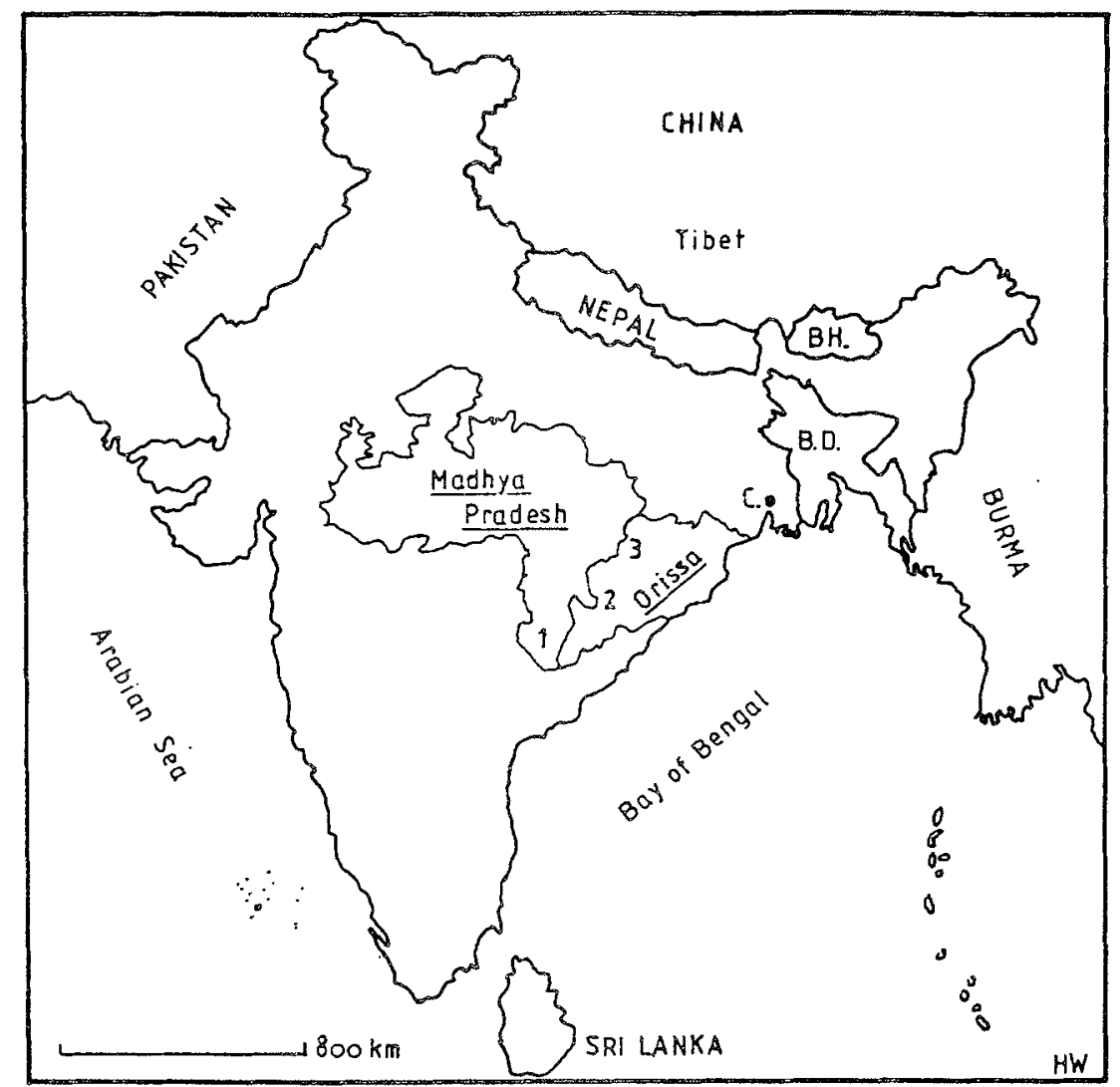

Fig. 1. Location of the investigated tribal populations. 1, Bastar District; 2, Kalahandi District; 3, Sambalpur District. BH., Bhutan; B.D., Bangla Desh; C., Calcutta.

agriculturists and divided into several exogamous clans; cross cousin marriage is commonly practised by them.

Halba. The Halba are settled in large numbers all around the Bastar District of Madhya Pradesh. Socially they are divided into two main endogamous sections having several endogamous clans, which are partly totemic. Cross cousin marriage is a rule among them. They have adopted Hinduism and speak an Indo-European language, called Halbi.

Bhatra. This group is living in the northern parts of the Bastar District of Madhya Pradesh. The Bhatra are settled agriculturists. They speak an IndoEuropean language, known as Bhatri, which appears to be a corrupt form of Halbi, and which is much influenced by some Oriyan dialects. This tribal group is divided into a number of subgroups, which behave as distinct endogamous groups. They claim that they came from the Warangal District in Andhra Pradesh (South India) 
as attendants (athpahria) with the first Raja of Bastar about 23 generations ago.

Muria. The Muria (which means most likely "aboriginal") belong to the great Gond group and are one of the major tribal populations of the Bastar District of Madhya Pradesh. They speak a Dravidian language and are prosperous and industrious cultivators, who prefer paddy cultivation. Anthropologically they belong also to the Proto-Australoids (Guha, 1935).

Maria. This tribal group is also part of the Gond group. It is, however, not clear, whether they are one of the earlier indigenous tribes whom the Gond have assimilated (Fuchs, 1973). They speak a Dravidian language and are mostly distributed in the Bastar District of Madhya Pradesh - where our samples came from-and the adjacent Chanda and Gadchiroli Districts of Maharashtra. The Maria are divided into two great sections: the Hill Maria and the Bison-horn Maria, to which our sample belongs. They are mainly food gatherers and live for most of the year on forest produce.

All these eight tribal populations are geographically and socially isolated from each other so that genetic contacts and thus gene flow among them can be practically excluded. The considerable genetic heterogeneity, which could be observed concerning the distribution of the allele frequencies of blood group, serum protein and red cell enzyme polymorphisms as well as that of haemoglobin variants (Walter et al., 1992, 1993; Das et al., 1993), is without doubt caused by locally acting genetic differentiation factors and could be preserved by this isolation. In this study it will be examined, how far the genetic heterogeneity of these Central Indian tribal populations can be confirmed by the analysis of the distribution of GM and KM allotypes.

\section{RESULTS AND DISCUSSION}

Table 2 shows the observed and expected GM phenotype frequencies of the eight tribal populations under study. Genetic equilibrium can be assumed for all of them. Some deviation from genetic equilibrium is only seen for the total material. The different GM phenotypes observed among these eight tribal populations can be explained by five different GM haplotypes, namely: $G M^{*} 1,17 ; 21,26$; $G M^{*} 1,17 ; 10,11,13,15,16 ; G M^{*} 1,2,17 ; 21,26 ; G M^{*} 1,3 ; 5,10,11,13,14,26$; and $G M^{*} 3$; $5,10,11,13,14,26$. It is worth mentioning that in the Kisan sample only four of these five $G M$ haplotypes occur: $G M^{*} 1,2,17,21,26$ is absent in them.

In addition to the GM phenotypes presented in Table 2, some uncommon ones could be observed, which were excluded from haplotype frequency estimations. There were two uncommon phenotypes in the Binjhal samples, namely GM $1 ; 13,15,16,21$, and three in the Bhatra sample, namely two cases of GM 1; 13,15,16, 21 and one case of GM 1,2;13,15,16,21. The possible haplotype combinations of these uncommon phenotypes might be: $G M^{*} 1,17 / G M^{*} 1 ; 13,15,16,21$, and $G M^{*} 1$, $2,17 / G M^{*} 1 ; 13,15,16,21$, respectively. However, because no family data are avail- 
Table 2. GM phenotype frequencies in eight Central Indian tribal populations.

\begin{tabular}{|c|c|c|c|c|c|c|c|c|c|c|}
\hline \multirow[t]{2}{*}{ GM phenotype } & \multicolumn{2}{|c|}{$\begin{array}{l}\text { Deshia } \\
\text { Khond }\end{array}$} & \multicolumn{2}{|c|}{ Binjhal } & \multicolumn{2}{|c|}{ Kisan } & \multicolumn{2}{|c|}{ Dhurwa } & \multicolumn{2}{|c|}{ Halba } \\
\hline & Obs. & Exp. & Obs. & Exp. & Obs & Exp. & Obs. & Exp. & Obs. & Exp. \\
\hline 1,$17 ; 21,26$ & - & 0.01 & - & 1.06 & - & 0.85 & - & 2.11 & - & 2.20 \\
\hline 1,$17 ; 10,11,13,15,16,26$ & - & 0.01 & - & 0.31 & - & 0.90 & - & 0.17 & - & 0.16 \\
\hline $1,2,17 ; 21,26$ & - & 0.03 & 1 & 1.45 & - & - & - & 0.17 & - & 2.75 \\
\hline $\begin{array}{l}1,3,17 ; 5,10,11,13,14 \\
21,26\end{array}$ & 2 & 1.95 & 20 & 17.22 & 19 & 16.40 & 25 & 20.44 & 28 & 21.24 \\
\hline$\frac{1,2,17 ; 10,11,13,15,16}{26}$ & - & 0.01 & - & 0.16 & - & 一 & - & 0.01 & - & 0.08 \\
\hline $\begin{array}{l}1,3,17 ; 5,10,11,13,14 \\
15,16,26\end{array}$ & 1 & 0.98 & 3 & 2.49 & 10 & 8.63 & 1 & 0.82 & 1 & 0.76 \\
\hline 1,$17 ; 10,11,13,15,16$ & - & $<0.01$ & - & 0.02 & - & 0.24 & $-<$ & $<0.01$ & - & $<0.01$ \\
\hline $\begin{array}{l}1,2,3,17 ; 5,10,11,13,14 \\
21,26\end{array}$ & 2 & 1.95 & 10 & 9.29 & - & - & 1 & 0.82 & 14 & 10.62 \\
\hline 1,$3 ; 5,10,11,13,14,26$ & 83 & 83.06 & 52 & 53.53 & 71 & 72.83 & 45 & 47.36 & 27 & 30.05 \\
\hline $3 ; 5,10,11,13,14,26$ & 11 & 11.01 & 16 & 16.47 & 6 & 6.15 & 2 & 2.10 & 19 & 21.14 \\
\hline Total & & 99.01 & 1021 & 102.00 & 106 & 106.00 & 74 & 74.00 & 89 & 89.00 \\
\hline$x^{2}$ & 0.0 & 66 & 2.3 & & 2.6 & 62 & 3.68 & & $9.0^{\prime}$ & \\
\hline $\mathrm{df}$ & 5 & & 5 & & 3 & & 5 & & 5 & \\
\hline $\mathrm{p}$ & ns & & ns & & ns & & ns & & ns & \\
\hline \multirow{2}{*}{ GM phenotype } & \multicolumn{2}{|c|}{ Bhatra } & \multicolumn{2}{|c|}{ Muria } & \multicolumn{2}{|c|}{ Maria } & \multicolumn{2}{|c|}{ Total } & & \\
\hline & Obs. & Exp. & Obs. & Exp. & Obs. & Exp. & Obs. & Exp. & & \\
\hline 1,$17 ; 21,26$ & - & 1.07 & - & 0.46 & - & 0.66 & - & 6.90 & & \\
\hline 1,$17 ; 10,11,13,15,16,26$ & - & 0.11 & - & 0.21 & - & 0.09 & - & 2.05 & & \\
\hline $1,2,17 ; 21,26$ & 1 & 0.81 & - & 0.43 & 1 & 1.24 & 3 & 5.66 & & \\
\hline $\begin{array}{l}1,3,17 ; 5,10,11,13,14 \\
21,26\end{array}$ & 18 & 15.91 & 13 & 11.50 & 14 & 12.41 & 1391 & 20.89 & & \\
\hline$\frac{1,2,17 ; 10,11,13,15,16}{26}$ & - & 0.04 & - & 0.08 & - & 0.06 & - & 0.72 & & \\
\hline $\begin{array}{l}1,3,17 ; 5,10,11,13,14 \\
15,16,26\end{array}$ & 1 & 0.84 & 3 & 2.65 & 1 & 0.84 & 21 & 17.93 & & \\
\hline 1,$17 ; 10,11,13,15,16$ & - & $<0.01$ & - & 0.03 & - & $<0.01$ & - & 0.15 & & \\
\hline $\begin{array}{l}1,2,3,17 ; 5,10,11,13,14 \\
21,26\end{array}$ & 5 & 5.18 & 5 & 4.42 & 9 & 8.63 & 46 & 42.23 & & \\
\hline 1,$3 ; 5,10,11,13,14,26$ & 48 & 48.86 & 44 & 44.76 & 39 & 39.73 & 4094 & 18.87 & & \\
\hline $3 ; 5,10,11,13,14,26$ & 10 & 10.18 & 26 & 26.45 & 18 & 18.34 & $108 \quad 1$ & 10.61 & & \\
\hline Total & & 83.00 & & 90.99 & & 82.00 & 7267 & 26.01 & & \\
\hline$x^{2}$ & \multicolumn{2}{|c|}{1.598} & \multicolumn{2}{|c|}{1.548} & \multicolumn{2}{|c|}{1.136} & \multicolumn{2}{|c|}{14.936} & & \\
\hline$\tilde{d f}$ & \multicolumn{2}{|c|}{5} & \multicolumn{2}{|c|}{5} & \multicolumn{2}{|c|}{5} & \multicolumn{2}{|c|}{5} & & \\
\hline $\mathrm{p}$ & \multicolumn{2}{|l|}{ ns } & \multicolumn{2}{|l|}{ ns } & \multicolumn{2}{|l|}{ ns } & \multicolumn{2}{|c|}{$0.05>p>0.01$} & & \\
\hline
\end{tabular}

able, this assumption remains speculative.

The GM haplotype distributions (Table 3 ) demonstrate a considerable intergroup variability, which is statistically highly significant as $\boldsymbol{\chi}_{(28)}^{2}=197.324, \mathrm{p}<$ 0.001 .

Table 4 displays the distribution of KM phenotype and allele frequencies among the eight tribal populations under study. The intergroup variability of the 
$K M^{*} I$ allele frequencies is also rather considerable and statistically significant as $\chi_{(7)}^{2}=15.820,0.05>\mathrm{p}>0.01$.

The genetic heterogeneity among the eight tribal populations is corroborated by the results of the principal component analysis (Fig. 2). Three eigenvalues, which in total explain ca. $90 \%$ of the variance show that especially the Kisan are quite different from all the other groups, which is mainly due to the absence of the $G M^{*} 1,2,17 ; 21,26$ haplotype (Table 3 ) and the comparatively high frequency of the $K M^{*} I$ allele (Table 4) in them. It is interesting to observe that just this AustroAsiatic speaking group is genetically so different from the Indo-European and Dravidian languages speaking groups. Though Indo-European languages speaking populations (Halba, Binjhal, Bhatra) and Dravidian languages speaking ones (Deshia Khond, Dhurwa, Maria, Muria) do not cluster separately they show nevertheless somewhat different positions in Fig. 2, which is due to the second principal component, in which the haplotypes $G M^{*} 1,17 ; 10,11,13,15,16$ and $G M^{*}$ $1,2,17 ; 21,26$ as well as the $K M^{*} I$ allele are having high loads. A detailed genetic distance pattern among these eight tribal populations, however, can be displayed

Table 3. GM haplotype frequencies in eight Central Indian tribal populations.

\begin{tabular}{|c|c|c|c|c|c|c|c|c|c|}
\hline \multirow[t]{2}{*}{ GM haplotype } & \multicolumn{2}{|c|}{$\begin{array}{l}\text { Deshia } \\
\text { Khond }\end{array}$} & \multicolumn{2}{|c|}{ Binjhal } & \multicolumn{2}{|c|}{ Kisan } & \multicolumn{2}{|c|}{ Dhurwa } & Halba \\
\hline & Freq. & $\mathrm{SE}$ & Freq. & $\mathrm{SE}$ & Freq. & $\mathrm{SE}$ & Freq. & $\mathrm{SE}$ & Freq. \\
\hline 1,$17 ; 21,26$ & 0.0101 & 0.0071 & 0.1019 & 0.0213 & 0.0896 & 0.0196 & 0.1689 & 0.0380 & $0.1573 \quad 0.0276$ \\
\hline 1,$17 ; 10,11,13,15,16$ & 0.0051 & 0.0050 & 0.0147 & 0.0084 & 0.0472 & 0.0146 & 0.0068 & 0.0067 & $0.0056 \quad 0.0056$ \\
\hline $1,2,17 ; 21,26$ & 0.0101 & 0.0071 & 0.0550 & 0.0161 & -- & - & 0.0068 & 0.0067 & $0.0787 \quad 0.0205$ \\
\hline 1,$3 ; 5,10,11,1$ & 0.6413 & 0.0478 & 0.4266 & 0.0454 & 0.6222 & 0.0496 & 0.6489 & 0.0622 & $0.2710 \quad 0.0422$ \\
\hline & 0.3334 & 0.0474 & 0.4018 & 0.0451 & 0.2410 & 0.0471 & 0.1686 & 0.0572 & $0.4874 \quad 0.0455$ \\
\hline \multirow{2}{*}{ GM haplotype } & \multicolumn{2}{|c|}{ Bhatra } & \multicolumn{2}{|c|}{ Muria } & \multicolumn{2}{|c|}{ Maria } & \multicolumn{2}{|c|}{ Total } & \\
\hline & Freq. & $\mathrm{SE}$ & Freq. & $\mathrm{SE}$ & Freq. & $\mathrm{SE}$ & Freq. & $\mathrm{SE}$ & \\
\hline 1,$17 ; 21,26$ & 0.1136 & 0.0247 & 0.0714 & 0.0191 & 0.0899 & 0.0225 & 0.0975 & 0.0078 & \\
\hline 1,$17 ; 10,11,13$ & 0.0060 & 0.0060 & 0.0165 & 0.0094 & 0.0061 & 0.0061 & 0.0145 & 0.0031 & \\
\hline $1,2,17 ; 21,26$ & 0.0370 & 0.0148 & 0.0275 & 0.0122 & 0.0625 & 0.0191 & 0.0340 & 0.0048 & \\
\hline 1,$3 ; 5,10,11,1$ & 0.4932 & 0.0526 & 0.3455 & 0.0426 & 0.3686 & 0.0474 & 0.4637 & 0.0172 & \\
\hline $3 ; 5,10,11,13$ & 0.3502 & 0.0513 & 0.5391 & 0.0440 & 0.4729 & 0.0484 & 0.3903 & 0.0170 & \\
\hline
\end{tabular}

Table 4. KM phenotype and allele frequencies in eight Central Indian tribal populations.

\begin{tabular}{|c|c|c|c|c|c|c|c|c|c|}
\hline & $\begin{array}{l}\text { Deshia } \\
\text { Khond }\end{array}$ & Binjhal & Kisan & Dhurwa & Halba & Bhatra & Muria & Maria & Total \\
\hline \multicolumn{10}{|c|}{$\overline{\mathrm{K}} \overline{\mathrm{M} \text { phenotype }}$} \\
\hline $1+$ & 19 & 24 & 27 & 8 & 20 & 17 & 8 & 12 & 135 \\
\hline $1-$ & 80 & 80 & 79 & 66 & 69 & 69 & 83 & 70 & 596 \\
\hline Total & 99 & 104 & 106 & 74 & 89 & 86 & 91 & 82 & 731 \\
\hline \multicolumn{10}{|c|}{$\mathrm{KM}$ allele frequency } \\
\hline$K M^{*} l$ & 0.1011 & 0.1229 & 0.1367 & 0.0556 & 0.1195 & 0.1043 & 0.0450 & 0.0761 & 0.0970 \\
\hline
\end{tabular}

Vol. 42, No. 1, 1997 
and discussed only considering all genetic markers available for these populations. Such an analysis is in progress. Unquestionably these eight tribal populations differ considerably in the distribution of GM haplotype and KM allele frequencies. This is in full agreement with our earlier mentioned observations on the variability of blood group, serum protein group, red cell enzyme group and haemoglobin allele frequencies (Walter et al., 1992, 1993; Das et al., 1993). This genetic heterogeneity can be attributed to the long-standing genetic isolation of these eight tribal groups, by which the results of locally acting genetic differentiation processes could be preserved.

Surveying the GM haplotypes shown in Table 3 it is apparent that two of them are arrays, which according to Steinberg and Cook (1981) are "Mongoloid" ones, namely $G M^{*} 1,17 ; 10,11,13,15,16$ and $G M^{*} 1,3,5 ; 10,11,13,14,26$. They are found, though in different frequencies, in all the eight tribal populations. Considering the distribution of GM haplotypes in other so far tested Indian populations it is striking, that these two haplotypes are generally found in all Indian tribal populations, whereas their occurrence in the non-tribal populations of India (castes or communities, e.g. Sikhs or Muslims) is either very low or they are even completely absent. This follows from studies on Punjabis (Daveau et al., 1980), higher and lower caste Hindus from Northwest India (Schanfield and Kirk, 1981), upper-caste Hindus from Bengal (Ray and Field, 1981), Sikhs (Field et al., 1988), and Brahmins, Kalitas, Kaibartas, and Muslims from Assam (Walter et al., 1987).

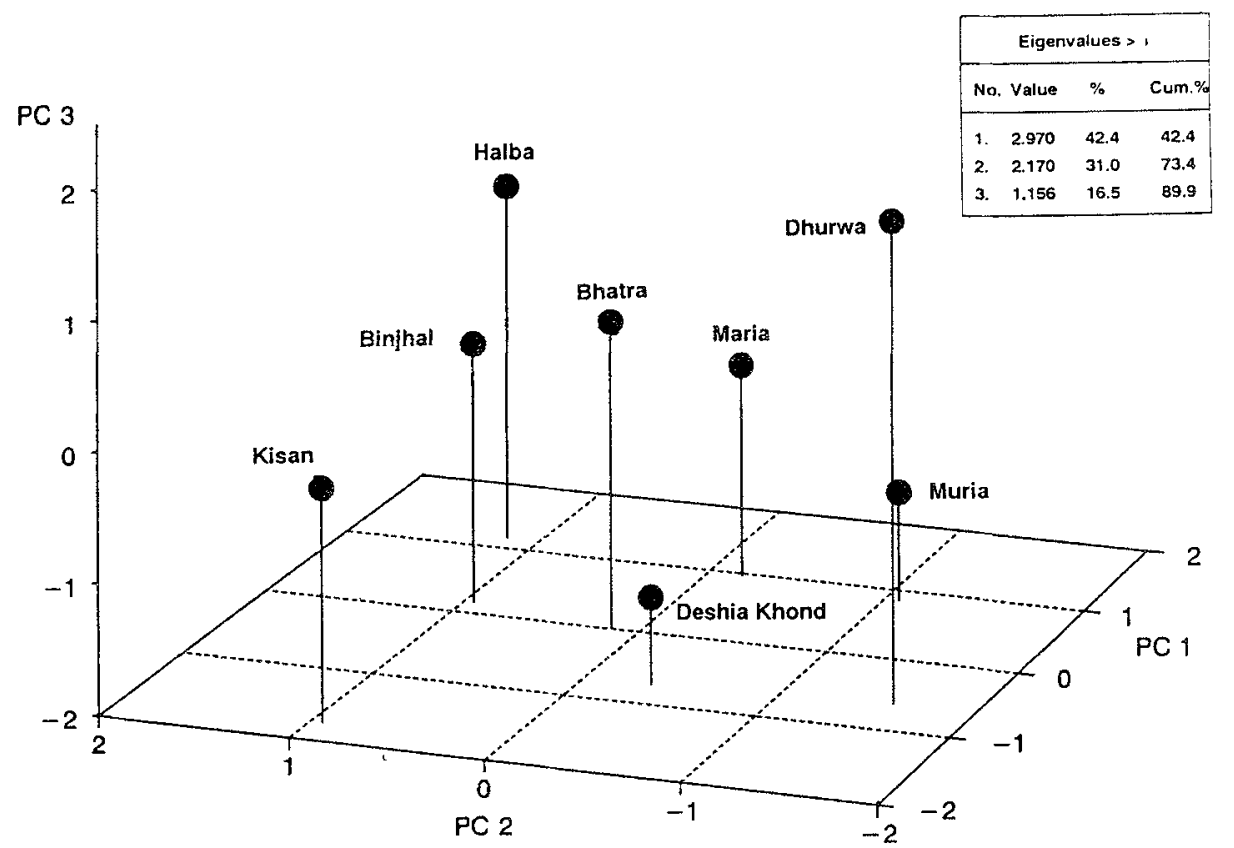

Fig. 2. Principal component analysis based on two polymorphic systems (GM and KM). 
All these population groups are characterized by the clear prevalence of the "Caucasoid" array of GM haplotypes, namely GM*1,17;21,26; GM*1,2,17;21,26; and $\mathrm{GM}^{*} 3 ; 5,10,11,13,14,26$. Concerning the occurrence of "Mongoloid" GM haplotypes in the Assamese caste and community populations Walter et al. (1987) suggested some gene flow from Mongoloid side, which could be substantiated considering the ethnohistory of Assam. The occurrence of "Mongoloid" haplotypes in Sikhs was explained by the possibility, that they may have characteristic of some of the Hindu castes in the Punjab, from which the Sikhs are descended (Field et al., 1988). It is left open, however, how these castes acquired "Mongoloid" GM haplotypes. At any rate larger samples from the various caste groups in that region are needed to provide more information relevant to that possibility as Field et al. (1988) suggested.

The fact is in any case that "Mongoloid" GM haplotypes are more or less rather frequent in all Indian tribal populations. How can this be explained? Matsumoto (1988) reported on the characteristics of Mongoloid and neighbouring populations based on the genetic markers of human immunoglobulins and could demonstrate a clear northeast-southwest gradient in the distribution of the two "Mongoloid" GM haplotypes mentioned above. The reasons for this gradient are seen in gene flow in connection with the expansion of Mongoloid populations and admixture during the past. Similar observations were obtained already previously by Schanfield and Gershowitz (1973), who also found a nonrandom distribution of GM haplotypes in Asia. Basing on GM typings on representative samples from Japan, Korea, China (Northern, Central, South Central, South) and Thailand (North, Central, South) they could observe, "that in a regular fashion the frequency of $\mathrm{Gm}^{\mathrm{a} b \mathrm{~b}}\left(=G M^{*} 1,3 ; 5\right)$ drops precipitously from south to north, while the frequencies of $\mathrm{Gm}^{\mathrm{ag}}\left(=G M^{*} 1 ; 21\right), \mathrm{Gm}^{\mathrm{axg}}\left(=G M^{*} 1,2 ; 21\right)$ and $\mathrm{Gm}^{\text {abst }}\left(=G M^{*} l\right.$; $5,15,16$ ) increase" (p. 572). They explain this cline with mixing, over the last several thousand years, of two populations, each characterized by markedly different distributions of $\mathrm{Gm}$ haplotypes: a southern population characterized by high levels of $\mathrm{Gm}^{\mathrm{afb}}$, low levels of $\mathrm{Gm}^{\mathrm{as}}$ and $\mathrm{Gm}^{\mathrm{axg}}$, and no $\mathrm{Gm}^{\mathrm{abst}}$; and a northern population characterized by high levels of $\mathrm{Gm}^{\mathrm{ag}}, \mathrm{Gm}^{\mathrm{axg}}$, and no $\mathrm{Gm}^{\mathrm{afb}}$. Concerning the tribal populations of Assam (Karbi, Kachari, Sonowal, Chutiya) as well as the Ahom group living in Assam it is well known that they are of Mongoloid origin and immigrated to India at different time and from different places in Southeast Asia, so that one can suppose that these populations imported their "Mongoloid" GM haplotypes to Assam (Northeast India). By intermixture these haplotypes were also introduced into populations of other genetic stock and geographical origin (e.g. Brahmins or Muslims).

Walter et al. (1991) reviewed critically all available data on the ethnohistory of the Indian tribal populations and concluded, that there is some evidence that the gene pool of those living in Central and Eastern parts of India seems to have been influenced by gene flow from Mongoloids. Thus, one can suppose that the 
occurrence of "Mongoloid" GM haplotypes observed in the investigated tribal populations of Madhya Pradesh and Orissa may reflect such gene flow, which possibly took place in ancient-history time. This assumption is corroborated by the distribution of the $D I^{*} A$ allele among the tribal groups under study (Walter et al., 1992). However, more and detailed GM studies on Indian tribal and nontribal populations from all regions of the country are needed in order to understand and to explain the distribution pattern of "Mongoloid" GM haplotypes in India in detail. This in connection with further archaeological and ethnological research of the ethnohistory of the populations of East and Central India would allow to explain definitely the distribution of "Mongoloid" haplotypes among Indian populations and its possible origin. Such studies, however, should also consider restriction fragment length polymorphisms associated with immunoglobulin heavy chain gamma genes as it was done e.g. by Propert et al. (1992) in their studies on Micronesians from Nauru.

\section{REFERENCES}

Bhasin MK, Walter H, Danker-Hopfe H (1992): The distribution of genetical, morphological, and behavioural traits among the people of Indian region (Bangladesh, Bhutan, India, Maldives, Nepal, Pakistan, Sri Lanka). Kamla-Raj Enterprises, Delhi

Das K, Roy M, Das MK, Sahu PN, Bhattacharya SK, Malhotra KC, Mukherjee BN, Walter H (1993): Study of the enzyme polymorphisms and haemoglobin patterns among sixteen tribal populations of Central India (Orissa, Madhya Pradesh and Maharashtra). Jpn J Human Genet 38: 297-313

Daveau M, Rivat L, Lalouel JM, Langaney A, Roberts DF, Simons MJ (1980): Frequencies of $\mathrm{Gm}$ and $\mathrm{Km}$ allotypes in the population of Singapore, Sri Lanka, and Punjab in North India. Hum Hered 30: 237-244

Field LL, Surje S, Ray AK (1988): Immunoglobulin (GM and KM) allotypes in the Sikh population of India. Am J Phys Anthropol 75: 31-35

Fuchs St (1973): The aboriginal tribes of India. The Macmillan Press, London, Basingstoke

Guha BS (1935): Racial affinities of the peoples of India. Census of India 1931. Vol. 1, Part III. The Government of India Press, Simla

Kurczynski TW, Steinberg AG (1967): A general program for maximum likelihood estimation of gene frequencies. Am J Hum Genet 19: 178-179

Matsumoto H (1988): Characteristics of Mongoloid and neighbouring populations based on the genetic markers of human immunoglobulins. Hum Genet 80: 207-218

Propert DN, Nandan R, Jazwinska EC (1992): GM and KM allotypes and GM RFLP allogenotypes in Micronesians from Nauru. Hum Biol 64: 17-24

Ray AK, Field LL (1981): Immunoglobulin (Gm) allotypes in a sample of upper-caste Hindus from Bengal, India. Hum Hered 31: 358-362

Risley HH (1915): The people of India. Thacker, Spink and Company, Calcutta

Schanfield MS, Gershowitz A (1973): Nonrandom distribution of Gm haplotypes in East Asia. Am J Hum Genet 25: $567-574$

Schanfield MS, Kirk RL (1981): Further studies on the immunoglobulin allotypes (Gm, Am, and $\mathrm{Km}$ ) in India. Acta Anthropogen 5: 1-21

Steinberg AG (1973): The Gm and Inv immunoglobulin allotypes in Indian populations. A review. In: Sanghvi LD (ed). Population genetics in India. Proc 1st Ann Conf Indian Soc Hum Genet Bombay, pp 112-126 
Steinberg AG, Cook CE (198I): The distribution of the human immunoglobulin allotypes. Oxford University Press, Oxford

Vos GH, Kirk RL, Steinberg AG (1963): The distribution of the gamma globulin types Gm (a), Gm (b), Gm (x) and Gm (like) in South and South-east Asia and Australia. Am J Hum Genet 15: 44-52

Walter H, Matsumoto H, Miyazaki T, Mukherjee BN, Malhotra KC, Das BM, Gilbert K, Lindenberg P (1987): Distribution of $\mathrm{Gm}$ and $\mathrm{Km}$ allotypes among ten populations of Assam, India. Am J Phys Anthropol 73: 439-445

Walter H, Danker-Hopfe H, Bhasin MK (1991): Anthropologie Indiens. Untersuchungen zur genetischen Variabilität der Bevölkerung Indiens mit besonderer Berücksichtigung ihrer regionalen, ethno-sozialen und sprachlichen Gliederung. Gustav Fischer Verlag, Stuttgart, New York

Walter H, Danker-Hopfe H, Eberhardt D, Tegeler M, Das MK, Das K, Bhattacharya SK, Sahu PN, Malhotra KC, Mukherjee BN (1992): Investigations on the variability of blood group polymorphisms among sixteen tribal populations from Orissa, Madyha Pradesh and Maharashtra, India. Z Morphol Anthropol 79: 69-94

Walter $\mathrm{H}$, Eberhardt D, Tegeler M, Wiechmann I, Danker-Hopfe $\mathrm{H}$, Bhattacharya SK, Das MK, Mukherjee BN, Das K (1993): HP, GC and PI polymorphism in sixteen central Indian tribal populations. Gene Geography 7: 193-202 